\title{
Impact of Protein and Certain Amino Acids Levels on Performance of Growing Japanese Quails
}

\author{
Alagawany M.", M.M. El-Hindawy , A. I. Attia \\ Poultry Department, Faculty of Agriculture, Zagazig University, Zagazig, 44111, Egypt \\ *Corresponding Author: dr.mahmoud.alagwany@gmail.com
}

Copyright $@ 2014$ Horizon Research Publishing All rights reserved.

\begin{abstract}
A $2 \times 2 \times 2$ factorial design experiment was carried out with two levels of protein (20 and $22 \%$ ), two levels of lysine (1.05 and $1.15 \%)$ and two levels of total sulfur amino acids (TSAA) (0.8 and $0.9 \%)$ to investigate their effect on growth performance and carcass characteristics of growing Japanese quail. A total number of 408 unsexed one week old Japanese quail chicks were randomly distributed into eight treatment groups of 51 chicks each with three replicates (each of 17 chicks). Live body weight at 21 and 42 days and feed intake during 21-42 days of age was significantly affected $(\mathrm{P}<0.05)$ by the interaction among protein, lysine and TSAA in growing Japanese quail diets. Effect of protein, lysine and TSAA or their interactions did not significantly $(\mathrm{P}>0.05)$ influences carcass traits. The results of economical efficiency indicated that the best economical efficiency was recorded by quail chicks fed $20 \%$ crude protein with $1.05 \%$ lysine and $0.8 \%$ TSAA up to 42 days of age.
\end{abstract}

Keywords Protein, Lysine TSAA, Quails, Economics

\section{Introduction}

Several dietary strategies can be used to reduce $\mathrm{N}$ excretion in poultry manure, including the supplementation of synthetic amino acid to low-protein diets, the utilization of hydroxy analogues or keto acids of amino acids to supplement low-protein diets, or the concept of a dietary ideal protein ratio. The ideal protein ratio concept has been previously reviewed in detail by (1). Briefly, this concept was conceived as a means to formulate diets based on meeting amino acid proportional requirements of animals for protein accretion and maintenance, while simultaneously avoiding deficiencies and excesses (2). Dietary manipulation approaches have also extensively focused on methionine and lysine as key amino acids for reducing poultry $\mathrm{N}$ excretion and associated pollution problems. A major issue facing the poultry industries is the impact of modern production on the environment (3). Therefore, reducing $\mathrm{N}$ excretion in poultry manure is an important first step toward to sustain environment. Formerly, dietary adjustments to poultry requirements were aimed at maximizing production performance without special concern for nutrient oversupply, especially protein and amino acids.

The concentration of dietary protein influences the requirement for TSAA in growing chicks (4). Depending on the range of protein levels used and the amino acid involved, the requirement has been reported as increasing in direct proportion to the concentration of dietary protein or, to increase, but at a slower rate than the rise in dietary protein. Some investigators have varied protein along with the amino acid concentration in estimating the requirements. (5) concluded that the diets which contain sulfur protein beyond that needed to maximize growth rate or feed efficiency, need supplementation with methionine beyond that required when dietary protein was adequate.

Methionine and lysine are generally the first and the next limiting amino acids in corn-soybean diets for laying hens. Moreover, methionine is considered the first limiting amino acid in low protein corn-soybean meal diet for laying hens. There is still controversy about this subject in the literature (6). Many studies have reported that the efficiency of protein utilization is increased by supplementation of methionine and lysine (7).

Modern statistical methods have been applied in most of these to obtain estimates of the requirements based on growth rate, feed efficiency and other measures. Studies of (8) and (9) confirmed the positive relationships of the lysine requirements to dietary protein level. Their studies demonstrated the linearity of the relationships between lysine, requirement and dietary protein level. The mechanism of these actions is unknown, but the amino acid imbalance may be the most important factor for amino acid needs. It is well known that protein, lysine and its interaction is considered as an important factor which affects performance and carcass quality of growing chicks and so, dietary requirements of protein is actually a requirement for the lysine contained in the protein.

Therefore, the present experiment was conducted to investigate the effect of protein and some essential amino acids levels on growth performance and carcass characteristic of growing Japanese quails. 


\section{Material and Methods}

The present investigation was carried out at Poultry Research Farm, Department of Poultry, Faculty of Agriculture, Zagazig University, Egypt. All experimental procedures were carried out according to the Local Experimental Animal Care Committee, and approved by the ethics of our institutional committee of Department of Poultry, Faculty of Agriculture, Zagazig University, Zagazig; Egypt.

A $2 \times 2 \times 2$ factorial design was conducted to study the effect of two levels of dietary crude protein (20 and $22 \%$ ), two levels of lysine (1.05 and $1.15 \%$ ) and two levels of total sulfur amino acids (0.8 and $0.9 \%)$ and their interaction on growth performance and carcass traits of Japanese quail during the growing period (7-42 days of age ).

A total number of 408 unsexed one week old Japanese quail chicks were randomly distributed into eight treatment groups of 51 chicks each with three replicates (each of 17 chicks). Chicks of all experimental groups had nearly the same initial average weight. Chicks were housed in conventional type cages with feed and water provided for ad libitum consumption and fed a diet formulated to meet nutrient requirements recommended commercially (Table 1). Lighting was $23 \mathrm{~h}$ light and $1 \mathrm{~h}$ darkness. Vaccination and medical program were done according to the different stages of age under supervision of a veterinarian. The composition and chemical analysis of the experimental diets as shown in Table (1).

Birds were weighed individually at weekly intervals. Mortality was recorded daily. Total feed intake was measured per pen weekly. Feed intake (PI) and feed conversion efficiency (FCE) (weight gain/feed intake) were adjusted for mortality. Three birds of each group were sampled randomly for carcass evaluations at 35 days of age and slaughtered and weighed. Their feathers were plucked manually, eviscerated by hand. Whole carcass, abdominal fat pad (excluding the gizzard fat), empty gizzard and proventriculus, liver, heart, pancreas and spleen were excised and weighed individually. The carcass yields were calculated as a percentage of the pre-slaughter live body weights of broiler chickens.

Table 1. Chemical composition of the experimental diets.

\begin{tabular}{|c|c|c|c|c|c|c|c|c|}
\hline \multirow{3}{*}{$\begin{array}{c}\text { Protein levels } \% \\
\text { Lysine levels \% } \\
\text { Methionine + cystine levels } \%\end{array}$} & \multicolumn{4}{|c|}{22} & \multicolumn{4}{|c|}{20} \\
\hline & \multicolumn{2}{|c|}{1.05} & \multicolumn{2}{|c|}{1.15} & \multicolumn{2}{|c|}{1.05} & \multicolumn{2}{|c|}{1.15} \\
\hline & 0.8 & 0.9 & 0.8 & 0.9 & 0.8 & 0.9 & 0.8 & 0.9 \\
\hline \multicolumn{9}{|l|}{ Ingredients, $\%$} \\
\hline yellw corn $\%$ & 62.00 & 63.00 & 62.30 & 63.00 & 66.00 & 66.00 & 66.00 & 66.00 \\
\hline Soybean meal (44\%) & 25.89 & 24.00 & 25.48 & 24.00 & 25.11 & 25.10 & 25.09 & 25.09 \\
\hline Corn gluten $(60 \%)$ & 8.50 & 9.55 & 8.55 & 9.45 & 4.94 & 4.84 & 4.85 & 4.75 \\
\hline Cotton seed oil & 0.29 & - & 0.23 & - & 0.50 & 0.50 & 0.50 & 0.50 \\
\hline $\mathrm{Nacl}$ & 0.30 & 0.30 & 0.30 & 0.30 & 0.30 & 0.30 & 0.30 & 0.30 \\
\hline Premix* & 0.30 & 0.30 & 0.30 & 0.30 & 0.30 & 0.30 & 0.30 & 0.30 \\
\hline Dicalium phosphate & 1.60 & 1.60 & 1.62 & 1.60 & 1.60 & 1.60 & 1.60 & 1.60 \\
\hline Limestone & 0.85 & 0.85 & 0.85 & 0.85 & 0.85 & 0.85 & 0.85 & 0.85 \\
\hline L- lysine & 0.06 & 0.11 & 0.17 & 0.21 & 0.11 & 0.11 & 0.21 & 0.21 \\
\hline Dl-methionine & - & 0.08 & - & 0.08 & 0.09 & 0.20 & 0.10 & 0.20 \\
\hline Choline chloride & 0.21 & 0.21 & 0.20 & 0.21 & 0.20 & 0.20 & 0.20 & 0.20 \\
\hline Total & 100.00 & 100.00 & 100.00 & 100.00 & 100.00 & 100.00 & 100.00 & 100.00 \\
\hline \multicolumn{9}{|l|}{ Calculated analysis } \\
\hline Crude protein, $\%$ & 22.01 & 22.00 & 22.00 & 22.07 & 20.00 & 20.00 & 20.02 & 20.07 \\
\hline $\mathrm{ME}(\mathrm{Kcal} / \mathrm{kg})$ & 2999 & 3004 & 3002 & 3005 & 3002 & 3002 & 3002 & 3002 \\
\hline Calcium, $\%$ & 0.80 & 0.80 & 0.80 & 0.80 & 0.80 & 0.80 & 0.80 & 0.80 \\
\hline P \% Available, & 0.45 & 0.45 & 0.45 & 0.45 & 0.45 & 0.45 & 0.45 & 0.45 \\
\hline Lysine, \% & 1.05 & 1.05 & 1.15 & 1. 15 & 1.05 & 1.05 & 1. 15 & 1.15 \\
\hline Methionine+Cystine, $\%$ & 0.80 & 0.90 & 0.80 & 0.90 & 0.80 & 0.90 & 0.80 & 0.90 \\
\hline Choline mg/Kg diet, & 2000 & 2000 & 2000 & 2000 & 2000 & 2000 & 2000 & 2000 \\
\hline Price/ ton/diet, 1.E.** & 1559 & 1570 & 1566 & 1583 & 1529 & 1551 & 1541 & 1562 \\
\hline
\end{tabular}

* Grower vit.and Min. Premix: Each 3 Kg consists of : Vit. A 12000.000 IU; Vit. D3, 2000.000 IU, Vit.E 10g; Vit. K3,2000mg; Vit. B1, 1000 Mg; Vit. B2, 5000 Mg; Vit. B6, 1500Mg, Vit. B12,10Mg; Biotin 50 Mg; Pantothenic acid, 10 g; Niacin, 30 g; Folic acid, $1000 \mathrm{Mg}$; Mn, 60 g; $\mathrm{Zn}, 50 \mathrm{~g} ; \mathrm{Cu} ; 10 \mathrm{~g} ; \mathrm{I}, 1000 \mathrm{Mg}$; Si, $100 \mathrm{Mg}$; Co.100Mg.

** Caculated according to the price of feed ingredients when the experiment was started. 
Table 2. Live body weight and weight gain for Japanese quail as affected by crude protein, lysine, total sulfur amino acids levels and their interaction during experimental periods.

\begin{tabular}{|c|c|c|c|c|c|c|}
\hline \multirow{2}{*}{ Items } & \multicolumn{3}{|c|}{ Live body weight } & \multicolumn{3}{|c|}{ Body weight gain } \\
\hline & 7 Days & 21 Days & 42 Days & 7- 21 Days & 21-42 Days & 7-42 Days \\
\hline \multicolumn{7}{|l|}{ Protein level \% } \\
\hline 20 & $22.81 \pm 0.05$ & $64.68 \pm 1.01$ & $157.67 \pm 2.01^{\mathrm{a}}$ & $2.99 \pm 0.06$ & $4.42 \pm 0.08^{\mathrm{a}}$ & $3.85 \pm 0.05^{\mathrm{a}}$ \\
\hline 22 & $22.76 \pm 0.05$ & $64.60 \pm 2.69$ & $151.18 \pm 2.79^{\mathrm{b}}$ & $2.98 \pm 0.19$ & $4.12 \pm 0.10^{\mathrm{b}}$ & $3.66 \pm 0.07^{\mathrm{b}}$ \\
\hline \multicolumn{7}{|l|}{ Lysine level \% } \\
\hline 1.05 & $22.75 \pm 0.05$ & $67.89 \pm 1.55^{\mathrm{a}}$ & $154.84 \pm 1.89$ & $3.22 \pm 0.10^{\mathrm{a}}$ & $4.14 \pm 0.10^{\mathrm{b}}$ & $3.77 \pm 0.05$ \\
\hline 1.15 & $22.82 \pm 0.05$ & $61.38 \pm 1.98^{\mathrm{b}}$ & $154.01 \pm 3.18$ & $2.75 \pm 0.13^{\mathrm{b}}$ & $4.41 \pm 0.08^{\mathrm{a}}$ & $3.74 \pm 0.08$ \\
\hline \multicolumn{7}{|l|}{ TSSA level $\%$} \\
\hline 0.80 & $22.77 \pm 0.06$ & $66.65 \pm 1.57^{\mathrm{a}}$ & $155.25 \pm 2.40$ & $3.13 \pm 0.10^{\mathrm{a}}$ & $4.22 \pm 0.09$ & $3.78 \pm 0.06$ \\
\hline 0.90 & $22.80 \pm 0.04$ & $62.62 \pm 2.24^{\mathrm{b}}$ & $153.60 \pm 2.80$ & $2.84 \pm 0.15^{\mathrm{b}}$ & $4.33 \pm 0.11$ & $3.73 \pm 0.08$ \\
\hline Two-way ANOVA & \multicolumn{6}{|c|}{ Probabilities } \\
\hline Protein & NS & NS & $*$ & NS & $*$ & $*$ \\
\hline Lysine & NS & $* *$ & NS & $* *$ & $*$ & NS \\
\hline TSAA & NS & $* *$ & NS & $* *$ & NS & NS \\
\hline Protein $\times$ Lysine & NS & $* *$ & $*$ & $* *$ & NS & $*$ \\
\hline Protein $\times$ TSAA & NS & NS & NS & NS & NS & NS \\
\hline Lysine $\times$ TSAA & NS & NS & NS & $*$ & NS & NS \\
\hline Protein $\times$ Lysine $\times$ TSAA & NS & $*$ & $*$ & NS & NS & NS \\
\hline
\end{tabular}

Means in the same column within each classification bearing different letters are significantly different $(\mathrm{P}<0.05$ or 0.01$)$.

Table 3. Feed intake and feed conversion ratio for Japanese quail as affected by crude protein, lysine, total sulfur amino acids levels and their interaction during experimental periods.

\begin{tabular}{|c|c|c|c|c|c|c|}
\hline \multirow[b]{2}{*}{ Items } & \multicolumn{3}{|c|}{ Feed intake } & \multicolumn{3}{|c|}{ Feed conversion ratio } \\
\hline & 7- 21 Days & 21-42 Days & 7-42 Days & 7- 21 Days & 21-42 Days & 7-42 Days \\
\hline \multicolumn{7}{|l|}{ Protein level \% } \\
\hline 20 & $10.68 \pm 0.20 \mathrm{~b}$ & $19.33 \pm 0.29 a$ & $15.87 \pm 0.18$ & $3.60 \pm 0.11 \mathrm{a}$ & $4.40 \pm 0.07$ & $4.12 \pm 0.04$ \\
\hline 22 & $11.41 \pm 0.28 \mathrm{a}$ & $18.53 \pm 0.21 b$ & $15.68 \pm 0.19$ & $3.98 \pm 0.23 b$ & $4.60 \pm 0.11$ & $4.29 \pm 0.08$ \\
\hline \multicolumn{7}{|l|}{ Lysine level \% } \\
\hline 1.05 & $11.52 \pm 0.25 \mathrm{a}$ & $18.74 \pm 0.01$ & $15.85 \pm 0.21$ & $3.61 \pm 0.10 \mathrm{a}$ & $4.62 \pm 0.09$ & $4.20 \pm 0.05$ \\
\hline 1.15 & $10.57 \pm 0.19 b$ & $19.12 \pm 0.26$ & $15.69 \pm 0.15$ & $3.98 \pm 0.23 \mathrm{~b}$ & $4.38 \pm 0.09$ & $4.21 \pm 0.08$ \\
\hline \multicolumn{7}{|l|}{ TSSA level \% } \\
\hline 0.80 & $10.87 \pm 0.25$ & $18.83 \pm 0.29$ & $15.64 \pm 0.18$ & $3.51 \pm 0.13 \mathrm{a}$ & $4.55 \pm 0.07$ & $4.14 \pm 0.05$ \\
\hline 0.90 & $11.23 \pm 0.27$ & $19.03 \pm 0.27$ & $15.90 \pm 0.19$ & $4.08 \pm 0.20 \mathrm{~b}$ & $4.45 \pm 0.11$ & $4.27 \pm 0.08$ \\
\hline Two-way ANOVA & \multicolumn{6}{|c|}{ Probabilities } \\
\hline Protein & $*$ & $*$ & NS & $* *$ & NS & NS \\
\hline Lysine & $* *$ & NS & NS & $*$ & NS & NS \\
\hline TSAA & NS & NS & NS & $* *$ & NS & NS \\
\hline Protein $\times$ Lysine & NS & NS & NS & $* *$ & NS & NS \\
\hline Protein $\times$ TSAA & NS & NS & NS & NS & NS & NS \\
\hline Lysine $\times$ TSAA & NS & NS & NS & NS & NS & NS \\
\hline Protein $\times$ Lysine $\times$ TSAA & NS & $*$ & NS & NS & NS & NS \\
\hline
\end{tabular}

Means in the same column within each classification bearing different letters are significantly different $(\mathrm{P}<0.05$ or 0.01$)$ 
In this experiment, all data were analyzed by ANOVA (SPSS 16) using a $2 \times 2 \times 2$ factorial arrangement of treatments with the pen being considered as the experimental unit. The model utilized included the effects of protein, lysine and TSAA, as well as the interaction effects:

$$
\mathrm{Y}_{\mathrm{ijk} 1}=\mu+\mathrm{A}_{\mathrm{i}}+\mathrm{S}_{\mathrm{j}}+\mathrm{L}_{\mathrm{k}}+\mathrm{AS}_{\mathrm{ij}}+\mathrm{AL}_{\mathrm{ik}}+\mathrm{SL}_{\mathrm{jk}}+\mathrm{ASL}_{\mathrm{ijk}}+\mathrm{e}_{\mathrm{ijk} 1}
$$

Where $: Y_{i j k 1}=$ an observation, $\mu=$ the overall mean, $A_{i}=$ effect of protein levels ( $\mathrm{i}=1$ to 2 ), $\mathrm{S}_{\mathrm{j}}=$ effect of lysine levels $(\mathrm{j}$ $=1$ to 2$), \mathrm{L}_{\mathrm{k}}=$ effect of TSAA levels $(\mathrm{k}=1$ to 2$), \mathrm{AS}_{\mathrm{ij}}=$ interaction between protein and lysine levels, $\mathrm{AL}_{\mathrm{ik}}=$ the interaction between protein and $\mathrm{TSAA}, \mathrm{SL}_{\mathrm{jk}}=$ interaction between lysine and TSAA levels, $\mathrm{ASL}_{\mathrm{ijk}}=$ the interaction a mange protein, lysine and TSAA levels, $e_{\mathrm{ijk} 1}=$ Experimental random error. Differences among means were determined using Duncan's New Multiple Range test (Duncan, 1955). Variability in the data is expressed as the standard error means (SEM) and a probability level of $\mathrm{P}<0.05$ was considered to be statistically significant.

\section{Results and Discussion}

Live body weight at 42 days and body weight gain during 21-42 and 7-42 days of age of chicks fed the $22 \%$ protein diet were increased compared with those obtained from the $20 \%$ protein diet (Table 2). These results confirmed the results obtained by (11). Also, (12) indicated that it is possible to reduce the CP feed level to $22 \%$ in Japanese quail diets during the growing period without significant effects on growth performance .

Daily feed intake was significantly $(\mathrm{P}<0.05)$ increased with $22 \%$ crude protein levels compared to $20 \% \mathrm{CP}$ diet during 21-42 days (Table 3). Contrary, during 7-21 days, birds fed $20 \%$ CP produced the lowest value $10.68 \mathrm{~g} / \mathrm{b} / \mathrm{d}$ of feed intake compared to the high level of CP diet. On the other hand, feed intake was not significantly affected by protein levels during the whole experimental period (7-42 days of age). This may be explained on the basis that chicks require more dietary protein in early stage of growth covered by increasing feed consumption. These results were partially agreed with (13) reported that broiler chicks feed $17 \%$ crude protein diet during 3-6 weeks of age showed insignificant differences in feed intake as compared to $20.5 \%$ crude protein level.

Data presented in Table 3 shows that, during 7-21 days, feed conversion ratio was significantly $(\mathrm{P}<0.01)$ improved with the $22 \% \mathrm{CP}$ level. While, $\mathrm{CP}$ levels had no significant effect on feed conversion ratio during 21-42 and 7-42 days. Contrary to that (14) stated that feed conversion was slightly improved with low protein diets ( 22 or $20 \%$ CP) in Japanese quail during 1-6 weeks of age.

The results obtained indicated significant improvement $(\mathrm{P}<0.01)$ in body weight at 21 days and body weight gain during 7-21 days of chicks fed on the diet contained 1.05\% lysine (Table 2). Whereas: Body weight gain during 21-42 days was significantly $(\mathrm{P}<0.05)$ improved as chicks were fed the diet containing $1.15 \%$ lysine. However, lysine levels had no significant effect on live body weight at 42 day and body weight gain during 7-42 day of age. On the same context, in broiler chicks, (15) found that increasing dietary lysine from 1.10 to $1.20 \%$ from 1 to 18 days in broilers improved $(\mathrm{P}<0.01)$ body weight gain and feed conversion.

During 7-21 days of age improved $(\mathrm{P}<0.05)$ feed intake and feed conversion values were noticed with $1.05 \%$ lysine. While, feed intake and feed conversion values during 21-42 and 7-42 days of age were not significantly affected by lysine levels (Table 3). Our results agreed with (16) who found that, increasing lysine in the diets significantly $(\mathrm{P}<0.01)$ increased feed consumption and improved feed conversion.

Results in Table 2 showed that, significant improvement $(\mathrm{P}<0.01)$ in body weight at 21 day and body weight gain during 7-21 day with $0.8 \%$ TSAA. However, the dietary level of TSAA had no significant effect on body weight at 42 days and body weight gain during 21-24 and 7-42 days of age. (17) demonstrated that meat type quails fed 0.95 and $0.73 \%$ methionine + cystine diets during the initial (7-21 days of age) and final period (22-42 days of age) of the growing phase show maximum weight gain. (18) found that the maximum value of body weight gain was achieved in Japanese quail with $0.75 \%$ TSAA during $0-6$ weeks of age. Also, (19) found that the quail chicks needed 0.74 TSAA for optimum growth from 0-3 weeks of age.

In broiler chicks (20) found that increasing the TSAA up to $0.79 \%$ during the finisher period by the addition of $0.15 \%$ DL-methionine resulted insignificant effect in body weight and body weight gain. (21) stated that body weight gain of birds fed 0.79 and $0.86 \%$ TSAA were significantly higher $(\mathrm{P}<0.05)$ then those fed $0.72 \%$ TSAA at 6 weeks of age.

The response to TSAA level for feed intake was not significant during all the experimental periods (Table 3 ). It could be noticed that birds fed on $0.9 \%$ TSAA had the high feed intake than those feed $0.8 \%$ TSAA. Our results agree with those obtained by (22) in broiler chicks, who found that feed intake did not differ significantly by TSAA level in the diet. Also, results in Table 3 showed significant improved $(\mathrm{P}<0.01)$ in feed conversion was realized for the diets containing 0.8 over $0.9 \%$ TSAA during $7-21$ days of age. But, no significant difference due to TSAA levels during 21-42 and 7-42 days of age. These results agreed with those obtained by (18) who found that at 3 weeks of age the feed efficiency in Japanese quail was maximized at 0.75 and $0.83 \%$ TSAA respectively. (23) found that the efficiency of feed utilization in broiler chicks was peaked with $0.93 \%$ TSAA diet.

Interaction between dietary protein and lysine levels were significant $(\mathrm{P}<0.05)$ on body weight at 21 and 42 days, taking body weight into consideration it could be concluded that the level of $20 \%$ crude protein with $1.05 \%$ lysine would be suitable for growing Japanese quail from 7 to 42 days of age. Results obtained in Tables 2 and 3 revealed that all growth performance traits studied were not significantly 
affected by interaction between dietary protein and TSAA levels during all the experimental periods. All growth performance traits were not significantly influenced by the tested levels of lysine and TSAA except average daily body weight gain during 7-21 days of age Tables 2 and 3. This means that about $1.05 \%$ dietary lysine with $0.9 \%$ TSAA was adequate for optimum body weight gain during 7-21 days of age in growing Japanese quail. Live body weight at 21 and 42 days and feed intake during 21-42 days of age were significantly affected $(\mathrm{P}<0.05)$ with the interaction between protein, lysine and TSAA in growing Japanese quail diets (Tables 2 and 3). At the same time feed conversion ratio and daily weight gain were not significantly affected during all the experimental periods (Tables 2 and 3).

\section{Carcass Criteria}

Results in Table 4 showed that the different levels of CP, lysine and TSAA or interaction between them did not have any consistent effect on all carcass traits studied (carcass\%, giblets $\%$, dressing\% and feather \%). Similarly (24) found that insignificant effect on all carcass traits of growing Japanese quail due to the different dietary protein levels (22, 24 and 26\%). Results reported herein are in agreement with the results documented by (25) who reported that CP levels had no significant effect on carcass dressing percentage of 56-day-old broiler chicks. Moreover, (26) found that CP level had insignificant effect on giblets and viscera percentage. Contradicting results were reported by (27) who found that slaughter and carcass weights showed a quadratic response to increasing dietary protein contents.

\section{Economical Efficiency}

Data presented in Table 4 showed that, the level of crude protein and the level of lysine did not have any consistent influence on economical efficiency value. But, economical feasibility value tended to decrease with increasing lysine level in the diet from 1.05 to $1.15 \%$. The results of economical efficiency indicated that the best economical efficiency was recorded by quail chicks fed $20 \%$ crude protein with $1.05 \%$ lysine and $0.8 \%$ TSAA up to 42 days of age.

In conclusion, from the nutritional and economical point of view, it could be concluded that, a dietary level of $20 \%$ crude protein with $1.05 \%$ lysine and $0.8 \%$ TSAA is recommended for the feeding of growing Japanese quail from 7 to 42 days of age.

Table 4. Some carcass traits for Japanese quail as affected by crude protein, lysine, total sulfur amino acids levels and their interaction at the end of experiment.

\begin{tabular}{|c|c|c|c|c|c|c|}
\hline \multirow[b]{2}{*}{ Items } & \multicolumn{6}{|c|}{ Carcass traits } \\
\hline & $\begin{array}{l}\text { Pre-slaughter } \\
\text { weight }(\mathrm{g})\end{array}$ & Carcass $\%$ & Giblet $\%$ & Dressing \% & Feather $\%$ & $\begin{array}{c}\text { Economical } \\
\text { efficiency }\end{array}$ \\
\hline \multicolumn{7}{|l|}{ Protein level \% } \\
\hline 20 & $158.34 \pm 2.58^{\mathrm{a}}$ & $72.89 \pm 0.38$ & $5.60 \pm 0.15$ & $78.51 \pm 0.35$ & $5.50 \pm 0.16$ & 0.350 \\
\hline 22 & $151.35 \pm 2.78^{b}$ & $73.30 \pm 0.69$ & $5.66 \pm 0.12$ & $79.13 \pm 0.58$ & $5.94 \pm 0.26$ & 0.337 \\
\hline \multicolumn{7}{|l|}{ Lysine level \% } \\
\hline 1.05 & $154.59 \pm 2.04$ & $72.55 \pm 0.58$ & $5.68 \pm 0.14$ & $78.42 \pm 0.53$ & $5.45 \pm 0.22$ & 0.347 \\
\hline 1.15 & $155.10 \pm 3.58$ & $73.65 \pm 0.49$ & $5.57 \pm 0.13$ & $79.21 \pm 0.41$ & $5.99 \pm 0.20$ & 0.344 \\
\hline \multicolumn{7}{|l|}{ TSSA level \% } \\
\hline 0.80 & $156.20 \pm 2.75$ & $73.21 \pm 0.54$ & $5.57 \pm 0.13$ & $78.96 \pm 0.45$ & $5.58 \pm 0.18$ & 0.359 \\
\hline 0.90 & $153.48 \pm 3.01$ & $72.98 \pm 0.58$ & $5.69 \pm 0.13$ & $78.67 \pm 0.52$ & $5.86 \pm 0.26$ & 0.331 \\
\hline Two-way ANOVA & \multicolumn{6}{|c|}{ Probabilities } \\
\hline Protein & $*$ & NS & NS & NS & NS & NS \\
\hline Lysine & NS & NS & NS & NS & NS & NS \\
\hline TSAA & NS & NS & NS & NS & NS & NS \\
\hline Protein $\times$ Lysine & $*$ & NS & NS & NS & NS & NS \\
\hline Protein $\times$ TSAA & NS & NS & NS & NS & NS & NS \\
\hline Lysine $\times$ TSAA & NS & NS & NS & NS & NS & NS \\
\hline $\begin{array}{c}\text { Protein } \times \text { Lysine } \times \\
\text { TSAA }\end{array}$ & $*$ & NS & NS & NS & NS & NS \\
\hline
\end{tabular}

Means in the same column within each classification bearing different letters are significantly different $(\mathrm{P}<0.05$ or 0.01$)$ 


\section{REFERENCES}

[1] Barker, D. H. (2003). Ideal Amino Acid Patterns For Broiler Chicks. In: Amino Acids In Animal Nutrition, 2nd Ed., J. P. F. D'mello. Cabi Publishing, Wallingford, Uk.

[2] Baker, D. H., A. B. Batal, T. M. Parr, N. R. Augspurger, and C. M. Parsons. (2002). Ideal Ratio (Relative To Lysine) Of Tryptophan, Threonine, Isoleucine, And Valine For Chicks During The Second And Third Weeks Post Hatch. Poult. Sci. $81: 485-494$

[3] Corzo, A., C. A. Fritts, M. T. Kidd and B. J. Kerr. (2005). Response Of Broiler Chicks To Essential And Nonessential Amino Acid Supplementation Of Low-Crude Protein Diets. Anim. Feed Sci. Technol. 118:319-327.

[4] Mendonca, C. X. and Jensen, L. S. (1989) Influence Of Protein Concentration On Sulfur -Containing Amino Acid Requirement Of Broiler Chickens. British Poultry Science, $30: 889-898$.

[5] Jensen, L.S, Wytt, C.L. and Fancher B.I. (1989) Sulpher Amino Acid Requirement Of Broiler Chicken From 3-6 Weeks Of Age. Poultry Science, 68 (1) 163-168.

[6] Abdel-Maksoud, A.; Yan, F.; Cerrate, S.; Coto, C.; Wang, Z. And Waldroup, P.W. (2010). Effect of dietary crude protein, lysine level and amino acid balance on performance of broilers 0 to 18 days of age. International Journal of Poultry Science 9: 21-27.

[7] Novak, C., H. M. Yakout, and S. Scheideler. (2004). The Combined Effects Of Dietary Lys And Total Sulfur Amino Acid Level On Egg Production Parameters And Egg Components In Dekalb Delta Laying Hens. Poult. Sci. 83:977-984.

[8] Abebe, S. and Morris, T.R. (1990a) Note On The Effects Of Protein Concentration On Response To Dietery Lysine By Chicks. British Poultry Science. 31:255-260.

[9] Surisdiarto and Farrell (1991) The Relationship Between Dietery Crude Protein And Dietary Lysine Requirement By Broiler Chicks On Diet With And Without The "Ideal" Amino Acid Balance. Poultry Science 70:830-836.

[10] Duncan, D. B. (1955) Multiple Range And Multiple F Tests. Biometrics, 11: 1-42.

[11] Alagawany M., Sonbol, S. M., El-Hendawy, M. M. and Attia, A. I. (2008) Effect Of Protein And Lysine Levels On Performance Of Growing Japanese Quail. Zagazig Veterinary Journal 36(1): 11-19.

[12] Minoguchi, N., Ohguch, H., Yamamoto, R. and Hanaki, Y.(2001). Low Protein Diets For Japanese Quail And The Reduction In Nitrogen Excretion. Reseaech Bulletin Of The Aichi Ken Agricultural Research Center, No., 33: 319-324.

[13] Jacob, J., Blair, R., Ibrahim, S., Scott, T. and Newberry, R. (1995) Using Low Protein Diets To Minimum Nitrogen Excretion Of Broilers. Poultry Science, 74 (Suppl. 1): 127
(Abstract)

[14] Ali, A.M, El-Nagmy, K.Y., and Abd-Alsamea, M.O. (2000) The Effect Of Dietary Protein And Yeast Culture Levels On Performance Of Growing Japanese Quails . Egyptian Poultry Science. Vol. 20 (Iv) Dec. 2000 (777-787).

[15] Kidd, M.T., Kerr, B.J. and Anthony, N.B. (1997) Dietary Interactions Between Lysine And Threonine In Broilers. Poultry Science, 76:608-614.

[16] Sterling, K. G., D. V. Vedenov, G. M. Pesti, and R. I. Bakalli. 2005. Economically Optimal Dietary Crude Protein And Lysine Levels For Starting Broiler Chicks. Poult. Sci. 84:29-36.

[17] Corrêa, G.S.S., Silva, M.A., Corrêa, A.B., Almeida, V., Fontes, D.O., Torres, R.A., Dionello, N.J.L.,

[18] Shrivastav, A.K. and Panda, B. (1986) Sulfur Amino Acid Requirement Of Growing Japanese Quail. Indian Journal Of Animal Science, 57:1303-1305.

[19] Svacha, A., Weber, C. W. and Reid, B. L. (1970) Lysine, Methionine And Glycine Requirements Of Japanese Quail To Five Weeks Of Age. Poultry Science, 49 : 54-59.

[20] Hassan, I. I. (1999) Effect Of Some Nutritional Treatments On Broiler Rations. Ph. D. Thesis, Faculty Of Agriculture Zagazig University, Egypt.

[21] Kassim, H. and Suwanpradit, S.(1996) The Effect Of Protein Level On The Total Sulpher Amino Acid Requirements Of Broilers During Two Growth Periods. Asian - Australasian Journal Of Animal Sciences, 9 (1):106 - 111.

[22] El-Anwar, E. M. M. and Attia, A. I. (2005) productive and economical performance of broiler chicks fed diets contained different levels of protein and total sulfur amino acid during winter season of Egypt. Egyptian Journal Applied Science, 20: $1-14$.

[23] Takahashi, K., Konashi, S., Akiba, Y. and Horiguchi, M. (1994) The Effects Of Dietary Methionine And Dispensable Amino Acid Supplementation On Abdominal Fat Deposition In Male Broilers. Animal Science Technology. 65: 3, 244 -250 .

[24] Aboul Ela, S. S., El Hindawy, M. M., Attia, A. I. and Ashore A.E. (2004) Protein And Energy Requirement Of Japanese Quail Under Egyptian Condition 1winter Season .Zagazig Journal Agricultural. Research.31:1045-1073.

[25] El-Naggar, N. M., Mehrez, A. Z., Aggor, F. A., Attia, Y.A. and Qota E.M.(1997) Carcass Composition, Yield, Physical Characteristics Of Meat And Serum Constituents. Egyptian Journal Poultry Science, 17: 107 - 132.

[26] Sherif, K. E. (1980) "Studies On Poultry Production" Effect Of Different Dietary Protein Levels On The Performance Of Growing Chicks. Master Science Thesis, Faculty Agriculture, Mansoura University Egypt.

[27] Kirkpinar, F. and Oguz, I. (1996) The Effects Of Dietary Protein Level On Performance Of Quail (Coturnix Coturnix Japonica). Ege Universitesi Ziraat Fakiiltesi Degisi , 33(213) 17-24. 